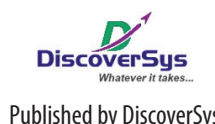

Published by DiscoverSys

\section{Sociodemographic factors and current contraceptive use among ever-married women of reproductive age: Analysis of the 2017 Indonesia Demographic and Health Survey data}

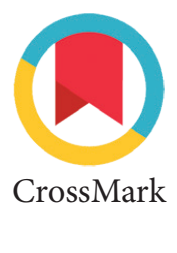

\author{
Ni Kadek Ayu Dwi Utami Ds, ${ }^{1 *}$ Dewa Nyoman Wirawan, ${ }^{2}$ Luh Seri Ani ${ }^{2}$
}

\title{
ABSTRACT
}

Background and purpose: Globally, the number of new contraceptive users in mid-2017 was only around half of the target. According to the results of the Indonesian Demographic and Health Survey (IDHS), the use of all methods of contraception in Indonesia has increased but is still lower than the target. This study aims to determine the factors associated with the use of contraception in Indonesia.

Methods: This study uses secondary data from the 2017 IDHS that was carried out in 34 provinces in Indonesia. The total sample was 35,681 of 49,627 women aged 15-49 years. The dependent variable was current contraceptive use. The independent variables consisted of sociodemographic and socio-economic factors, knowledge, discussion with husband, and access to health services. Data analysis was performed through a binary logistic regression test to obtain the adjusted odd ratio of each factor.

Results: The proportion of current contraceptive use was found to be 63.6\% (95\%Cl: 63.2-64.0\%). Factors related to current contraceptive use were family planning information from health workers $(A O R=1.67$;
95\%Cl: 1.59-1.77), maternal age of 35-44 years ( $A O R=1.54 ; 95 \% \mathrm{Cl}$ : 1.42-1.66), maternal age of $25-34$ years ( $A O R=1.37 ; 95 \% \mathrm{Cl}: 1.27-1.48$ ), maternal age $\geq 45$ years ( $A O R=0.75 ; 95 \% \mathrm{Cl}: 0.68-0.82$ ), living in the Java-Bali region ( $A O R=1.28 ; 95 \% \mathrm{Cl}: 1.22-1.35)$, living in rural areas $(A O R=1.07 ; 95 \% C l: 1.01-1.12)$, having more than two living children $(A O R=1.52 ; 95 \% C l: 1.44-1.60)$, level of education not attending school until not graduating from high school ( $A O R=1,46 ; 95 \% \mathrm{Cl}$ : 1.35-1.59), high school graduation level $(A O R=1.25 ; 95 \% \mathrm{Cl}: 1.16-1.35)$, not working status ( $A O R=1.08 ; 95 \% \mathrm{Cl}: 1.03-1.13)$, medium wealth index ( $A O R=1.07$; 95\%Cl: $1.00-1.14)$ and good knowledge (AOR=1.17; 95\%Cl: 1.11-1.23). Conclusion: The proportion of current contraceptive use in couples of childbearing age in Indonesia has not reached the government target. Factors that were more likely to increase current contraceptive use were family planning information from health workers, age, region, number of living children, mothers' education, and knowledge. The family planning program in Indonesia should therefore consider those factors to increase the current contraceptive use.

Keywords: contraception, family planning, factors, Indonesia

Cite This Article: Utami Ds, N.K.A.D., Wirawan, D.N., Ani, L.S. 2019. Sociodemographic factors and current contraceptive use among ever-married women of reproductive age: Analysis of the 2017 Indonesia Demographic and Health Survey data. Public Health and Preventive Medicine Archive 7(2): 95-102. D0l:10.15562/phpma.v7i2.211

'Public Health Postgraduate Program, Faculty of Medicine, Udayana University,

${ }^{2}$ Department of Public Health and Preventive Medicine, Faculty of Medicine, Udayana University
*Correspondence to: Ni Kadek Ayu Dwi Utami Ds, Public Health Postgraduate Program, Faculty of Medicine, Udayana University,

ayudwids@gmail.com

\section{INTRODUCTION}

Globally, Family Planning 2020 (FP 2020) sets a goal of 120 million new contraceptive users over eight years (between 2012-2020) or 15 million per year. ${ }^{1}$ Thus, about 75 million new contraceptive users should be achieved by mid-2017, but so far reached only 38.8 million, or about $52 \%$ coverage. $^{1}$

Use of all methods of contraception in the world in 2017 was reported at $63 \%$ with contraceptive use of above $70 \%$ found in Europe, Latin America and the Caribbean, and North America, while contraceptive use below 25 percent was found in Central and West Africa. The proportion of contraceptive use in Asia was $66.4 \%$ and in Southeast Asia 63.6\%, and in Indonesia $61.6 \%$ - lower compared to Thailand (78.4\%), Vietnam (76.7\%), Singapore (66.3\%). ${ }^{2}$

The Government of Indonesia has a commitment to guarantee family planning services for more than 30 million fertile age couples and ensure accessibility to at least 2.8 million additional users. ${ }^{3}$ The Indonesian government ensures the provision of contraceptive services through national health insurance schemes, increased mix of contraception methods, quality of service, contraceptive supply chain management, youth empowerment, and inter-sectoral cohesiveness at the central and regional levels. ${ }^{3}$

Based on the results of the Indonesian Demographic and Health Survey (IDHS), the use of contraception for all methods in Indonesia has increased from $61.9 \%$ in 2012 to $63.6 \%$ in 2017 but is still lower than the government target at the end of the 2015-2019 Government Planning or called RPJMN (Rencana Pemerintah Jangka Menengah Nasional) at $66 \% .^{4-6}$

Studies on factors related to the use of contraception has been widely carried out in various countries 
including Indonesia with inconsistent results. A study in Bangladesh shows that factors contributing to contraceptive use are age, family size, wealth index, mother's and husband's education, occupation, breastfeeding history, and childbirth in the past five years. ${ }^{7}$ Whereas a study in Ghana found no significant association between contraceptive use and age, marital status, employment, number of living children, antenatal care visits, and family planning discussions at postnatal services. ${ }^{8}$

A study in Indonesia that used secondary data analysis of the 1997 and 2007 IDHS found that the most dominant factor related to current contraceptive use was the husband's view of family planning. ${ }^{9}$ Within almost a decade there have been several changes in various aspects in Indonesia such as infrastructure, social, economic and health aspects, especially with the introduction of the National Health Insurance Program (JKN), where contraceptive services are also included. ${ }^{10,11}$ There has not been any publication of factors related to the use of contraception using the 2017 IDHS data. Aim of this study is to determine the factors related to contraception use in Indonesia using the 2017 IDHS data.

\section{METHODS}

This study uses secondary data from the 2017 IDHS which were downloaded online from www. sdki.bkkbn.go.id after registration and notification via electronic mail to the National Population and Family Planning Agency or called Badan Kependudukan dan Keluarga Berencana Nasional $(B K K B N)$. The 2017 IDHS is a national survey conducted on 49,627 women of childbearing age (15-49 years). Detailed information about the study design, sampling methods, sample size calculations, questionnaires, data collection procedures and other survey procedures are available in the 2017 IDHS report. ${ }^{12}$

The unit of analysis in our study was 35,681 women of childbearing age (15-49 years) who were married or living together, while 13,946 women who were not married and divorced were not included in the analysis. The dependent variable is current contraceptive use and the independent variables consist of socio-demographic characteristics (mother's age, area of residence, region, and number of living children), socio-economic factors (education, mother's occupation, and wealth index), knowledge, discussions with husband and access to services (health insurance, field staff visits and family planning information from the media and health workers).

Mothers' age is grouped into 15-24, 25-34, 35-44 and $\geq 45$ years. Residential area is grouped into urban and rural areas and regional area grouped into outside Java-Bali and Java-Bali. The number of living children is grouped into $\leq 2$ and $>2$, and education levels into university, high school graduate, and no school-ungraduate high school. Employment status is grouped into employed and unemployed, while the wealth index consists of poor, middle, and wealthy groups. Knowledge is grouped into poor and good, discussions with the husband grouped into never and ever, while health insurance is grouped into yes and no. Family planning information from media and health workers is grouped into yes and no, while field staff visit is grouped into never and ever.

Bivariate analysis with chi-square test was carried out to determine differences of current contraceptive use by characteristics of women in childbearing age. Variables with $\mathrm{p}<0.25$ then included in multivariate analysis. Multivariate analysis was performed with binomial logistic regression using the backward method to obtain the adjusted odd ratio of each variable. This study has been approved by the Ethics Committee of the Faculty of Medicine, Udayana University/Sanglah General Hospital on March 26, 2019.

\section{RESULTS}

The number of contraceptive use among 35,681 women currently married/living together age 15-49 years in Indonesia in 2017 was 22,696 or $63.6 \%$ (95\%CI: 63.2-64\%).

Table 1 presents the characteristics of respondents. Most respondents are aged 35-44 years old, live in the village, are in the Java-Bali region, have $\leq 2$ living children, primary education level, are employed, in the wealthy group of wealth index, poor knowledge, did not have discussions with their husbands, have health insurance, received family planning information from the media, did not get family planning information from health workers and had not been visited by field workers.

Table 2 presents the proportion of current contraceptive use based on several variables. It can be seen that the mother's age, place of residence, region, number of living children, education, employment, wealth index, knowledge, family planning discussions with husband, family planning information from the media and health workers and visits by health workers are significantly associated with current contraceptive use $(\mathrm{p}<0.05)$.

Table 3 presents the results of multivariate analysis with logistic regression using backward method. The dominant factors that increase the likelihood of using contraception are the age of the mother 35-44 years (AOR=1.54; 95\%CI: $1.42-1.66)$, and the age of the mother 25-34 years 
Table 1 Respondents' characteristics

\begin{tabular}{|c|c|c|c|}
\hline Characteristics & & $\mathbf{n}$ & $\%$ \\
\hline \multirow[t]{4}{*}{ Mothers' age (years) } & $15-24$ & 4,017 & 11.3 \\
\hline & $25-34$ & 12,119 & 34.0 \\
\hline & $35-44$ & 13,687 & 38.4 \\
\hline & $\geq 45$ & 5,858 & 16.4 \\
\hline \multirow[t]{2}{*}{ Area of residence } & Urban & 17,268 & 48.4 \\
\hline & Rural & 18,413 & 51.6 \\
\hline \multirow[t]{2}{*}{ Region } & Outside Java-Bali & 14,024 & 39.3 \\
\hline & Java-Bali & 21,656 & 60.7 \\
\hline \multirow[t]{2}{*}{ Number of living children } & $\leq 2$ & 24,688 & 69.2 \\
\hline & $>2$ & 10,993 & 30.8 \\
\hline \multirow[t]{3}{*}{ Education } & University & 4,375 & 12.3 \\
\hline & High school graduate & 9,309 & 26.1 \\
\hline & No school-ungraduate high school & 21,996 & 61.6 \\
\hline \multirow[t]{2}{*}{ Employment $^{*}$} & Employed & 21,990 & 61.6 \\
\hline & Unemployed & 13,686 & 38.4 \\
\hline \multirow[t]{3}{*}{ Wealth index } & Poor & 13,396 & 37.5 \\
\hline & Middle & 7,388 & 20.7 \\
\hline & Wealthy & 14,896 & 41.7 \\
\hline \multirow[t]{2}{*}{ Knowledge } & Poor & 23,356 & 65.5 \\
\hline & Good & 12,325 & 34.5 \\
\hline \multirow[t]{2}{*}{ Discussions with husband ${ }^{*}$} & Never & 21,750 & 61.0 \\
\hline & Ever & 13,905 & 39.0 \\
\hline \multirow[t]{2}{*}{ Health insurance ${ }^{\star}$} & No & 14,832 & 41.6 \\
\hline & Yes & 20,844 & 58.4 \\
\hline \multirow[t]{2}{*}{ Received information from media* } & No & 14,649 & 41.1 \\
\hline & Yes & 20,999 & 58.9 \\
\hline \multirow[t]{2}{*}{$\begin{array}{l}\text { Received information from health } \\
\text { workers* }\end{array}$} & No & 26,192 & 73.5 \\
\hline & Yes & 9,444 & 26.5 \\
\hline \multirow[t]{2}{*}{ Health worker visits* } & Never & 34,438 & 96.5 \\
\hline & Ever & 1,232 & 3.5 \\
\hline Total & & 35,681 & 100.0 \\
\hline
\end{tabular}

${ }^{*}$ Number less than 35,681 due to data missing

Table 2 Proportion of current contraceptive use by several variables in Indonesia

\begin{tabular}{lccc}
\hline & \multicolumn{2}{c}{ Current contraceptive use } \\
\cline { 2 - 3 } Variable & $\begin{array}{c}\text { Yes } \\
\mathbf{n}(\%)\end{array}$ & $\begin{array}{c}\text { No } \\
\mathbf{n}(\%)\end{array}$ & $\mathbf{p}$ \\
\hline Mother's age (years) & & & \\
$15-24$ & $2,283(56.8)$ & $1,734(43.2)$ & \\
$25-34$ & $7,821(64.5)$ & $4,298(35.5)$ & $<0.01$ \\
$35-44$ & $9,492(69.4)$ & $4,195(30.6)$ & \\
$\geq 45$ & $3,099(52.9)$ & $2,759(47.1)$ & \\
\hline
\end{tabular}




\begin{tabular}{|c|c|c|c|}
\hline \multirow[b]{2}{*}{ Variable } & \multicolumn{2}{|c|}{ Current contraceptive use } & \multirow[b]{2}{*}{$\mathbf{p}$} \\
\hline & $\begin{array}{c}\text { Yes } \\
\text { n (\%) }\end{array}$ & $\begin{array}{c}\text { No } \\
\text { n (\%) }\end{array}$ & \\
\hline \multicolumn{4}{|l|}{ Place of residence } \\
\hline Urban & $10,883(63.0)$ & $6,384(37.0)$ & 0.03 \\
\hline Rural & $11,812(64.2)$ & $6,601(35.8)$ & \\
\hline \multicolumn{4}{|l|}{ Region } \\
\hline Outside Java-Bali & $8,522(60.8)$ & $5,502(39.2)$ & $<0.01$ \\
\hline Java-Bali & $14,173(65.4)$ & $7,483(34.6)$ & \\
\hline \multicolumn{4}{|l|}{ Number of living children } \\
\hline$\leq 2$ & $15,088(61.1)$ & $9.600(38,9)$ & $<0.01$ \\
\hline$>2$ & $7,608(69.2)$ & $3.385(30,8)$ & \\
\hline \multicolumn{4}{|l|}{ Education } \\
\hline University & $2,493(57.0)$ & $1,882(43.0)$ & $<0.01$ \\
\hline High school graduate & $5,811(62.4)$ & $3,499(37.6)$ & \\
\hline No school-ungraduate high school & $14,392(65.4)$ & $7,604(34.6)$ & \\
\hline \multicolumn{4}{|l|}{ Employment } \\
\hline Employed & $8,952(65.4)$ & $4,733(34.6)$ & $<0.01$ \\
\hline Unemployed & $13,743(62.5)$ & $8,252(37.5)$ & \\
\hline \multicolumn{4}{|l|}{ Wealth Index } \\
\hline Poor & $8,523(63.6)$ & $4,874(36.4)$ & $<0.01$ \\
\hline Middle & $4,842(65.5)$ & $2,546(34.5)$ & \\
\hline Wealthy & $9,331(62.6)$ & $5,565(37.4)$ & \\
\hline \multicolumn{4}{|l|}{ Knowledge } \\
\hline Poor & $14,640(62.7)$ & $8,716(37.3)$ & $<0.01$ \\
\hline Good & $8,055(65.4)$ & $4,269(34.6)$ & \\
\hline \multicolumn{4}{|l|}{ Discussions with husband ${ }^{\star}$} \\
\hline Never & $13,657(62.8)$ & $8,093(37.2)$ & $<0.01$ \\
\hline Ever & $9,024(64.9)$ & $4,881(35.1)$ & \\
\hline \multicolumn{4}{|l|}{ Health Insurance ${ }^{\star}$} \\
\hline No & $9,388(63.3)$ & $5,444(36.7)$ & 0.30 \\
\hline Yes & $13,304(63.8)$ & $7,539(36.2)$ & \\
\hline \multicolumn{4}{|l|}{ Received information from media* } \\
\hline No & $9,082(62.0)$ & $5,567(38.0)$ & $<0.01$ \\
\hline Yes & $13,595(64.7)$ & $7,403(35.3)$ & \\
\hline \multicolumn{4}{|l|}{$\begin{array}{l}\text { Received information from health care } \\
\text { worker }^{\star}\end{array}$} \\
\hline No & $15,813(60.4)$ & $10,378(39.6)$ & $<0.01$ \\
\hline Yes & $6,855(72.6)$ & $2,589(27.4)$ & \\
\hline \multicolumn{4}{|l|}{ Health worker visits* } \\
\hline Never & $21,830(63.4)$ & $12,608(36.6)$ & $<0.01$ \\
\hline Ever & $859(69.7)$ & $374(30.3)$ & \\
\hline
\end{tabular}

${ }^{*}$ Number less than 35,681 due to data missing 


\begin{tabular}{|c|c|c|c|c|}
\hline \multirow[b]{2}{*}{ Variable } & \multirow[b]{2}{*}{ AOR } & \multicolumn{2}{|c|}{$95 \% \mathrm{Cl}$} & \multirow[t]{2}{*}{$\mathbf{p}$} \\
\hline & & Lower & Upper & \\
\hline \multicolumn{5}{|l|}{ Mother's age (years) } \\
\hline $15-24$ & Ref & & & \\
\hline $25-34$ & 1.37 & 1.27 & 1.48 & $<0.01$ \\
\hline $35-44$ & 1.54 & 1.42 & 1.66 & $<0.01$ \\
\hline$\geq 45$ & 0.75 & 0.68 & 0.82 & $<0.01$ \\
\hline \multicolumn{5}{|l|}{ Place of residence } \\
\hline Urban & Ref & & & \\
\hline Rural & 1.07 & 1.01 & 1.12 & $<0.01$ \\
\hline \multicolumn{5}{|l|}{ Region } \\
\hline Outside Java-Bali & Ref & & & \\
\hline Java-Bali & 1.28 & 1.22 & 1.35 & $<0.01$ \\
\hline \multicolumn{5}{|l|}{ Number of living children } \\
\hline$\leq 2$ & Ref & & & \\
\hline$>2$ & 1.52 & 1.44 & 1.60 & $<0.01$ \\
\hline \multicolumn{5}{|l|}{ Education } \\
\hline University & Ref & & & \\
\hline High school graduate & 1.25 & 1.16 & 1.35 & $<0.01$ \\
\hline No school-ungraduate high school & 1.46 & 1.35 & 1.59 & $<0.01$ \\
\hline \multicolumn{5}{|l|}{ Employment } \\
\hline Employed & Ref & & & \\
\hline Unemployed & 1.08 & 1.03 & 1.13 & $<0.01$ \\
\hline \multicolumn{5}{|l|}{ Wealth index } \\
\hline Poor & Ref & & & \\
\hline Middle & 1.07 & 1.00 & 1.14 & 0.03 \\
\hline Wealthy & 0.99 & 0.93 & 1.05 & 0.80 \\
\hline \multicolumn{5}{|l|}{ Knowledge } \\
\hline Poor & Ref & & & \\
\hline Good & 1.17 & 1.11 & 1.23 & $<0.01$ \\
\hline \multicolumn{5}{|l|}{ Received information from media } \\
\hline No & Ref & & & \\
\hline Yes & 1.04 & 0.99 & 1.09 & 0.10 \\
\hline \multicolumn{5}{|c|}{ Received information from health worker } \\
\hline No & Ref & & & \\
\hline Yes & 1.67 & 1.59 & 1.77 & $<0.01$ \\
\hline
\end{tabular}

$(\mathrm{AOR}=1.37 ; 95 \% \mathrm{CI}: 1.27-1.48)$ in the Java-Bali region $(\mathrm{AOR}=1.28$; 95\%CI: $1.22-1.35)$, having more than two living children (AOR=1.52; 95\%CI: 1.44$1.60)$, primary education level ( $\mathrm{AOR}=1.46 ; 95 \% \mathrm{CI}$ : 1.35-1.59), secondary education level $(\mathrm{AOR}=1.25$; 95\%CI: 1.16-1.35), has a good level of knowledge $(\mathrm{AOR}=1.17 ; 95 \% \mathrm{CI}: 1.11-1.23)$ and receipt of family planning information from health workers (AOR=1.67; 95\%CI: 1.59-1.77).

Other variables that were more likely to use contraception but with a smaller AOR were living in rural areas $(\mathrm{AOR}=1.07 ; 95 \% \mathrm{CI}$ : 1.01-1.12), unemployed $(\mathrm{AOR}=1.08 ; 95 \% \mathrm{CI}: 1.03-1.13)$, is in the middle wealth index range $(\mathrm{AOR}=1.07 ; 95 \% \mathrm{CI}$ : 1.00-1.14). While mothers aged $\geq 45$ years were less likely to use contraceptives $(\mathrm{AOR}=0.75 ; 95 \% \mathrm{CI}$ : 0.68-0.82).

\section{DISCUSSION}

The proportion of current contraceptive use in Indonesia in our analysis is $63.6 \%(95 \% \mathrm{CI}$ : 
$63.2 \%-64 \%)$. This proportion is still lower than the $66 \%$ government target at the end of the 2015-2019. ${ }^{6}$

The most dominant factor related to current contraceptive use in Indonesia is family planning information from health workers. Other associated factors with AOR lower than family planning information from health workers are age 25-34 and 35-44 years, having more than two living children, education of no school-ungraduate high school, living in Java-Bali and good knowledge. Area of residence, employment and wealth index are statistically significant associated with current contraceptive use but are not programmatically significant because the lower value of the confidence interval is close to one.

Receiving family planning information from health workers is increasing the current contraceptive use, may be due to the trust of the women to health workers as a professional who can provide advice and consultations about side effects and alternative contraceptive methods, thereby affecting the women decision to use contraception. ${ }^{13}$ A study in Myanmar showed that women who received good support from health workers were 15 times more likely to use contraception compared to those who received less support. ${ }^{14}$ Another study conducted in Ghana also shows that the main source of family planning information is health workers who are widely available in the community to provide health services. ${ }^{15}$

In our analysis, it was found that the other dominant factor was maternal age of 25-44 years. This is likely because women over the age of 45 are approaching menopause and have a perception of being unable to have children (perception of infecund) so they do not use contraception, while women under the age of 25 years may still want a pregnancy. ${ }^{16-18}$

Another factor related to current contraceptive use is having more than 2 living children. This is probably due to the fact that mothers who have more than two children tend to start limiting or spacing their pregnancies. ${ }^{19}$ In addition, it may also related to the family planning campaign that has long been introduced in Indonesia, which is "Two children are enough: A boy or a girl is the same". This is consistent with the average ideal number of desired children in the 2017 IDHS, which is 2.4 children. ${ }^{12}$

The results of our analysis show that women with lower levels of education were more likely to use contraceptives. Wealth indexes are also statistically found to be related to current contraceptive use but are not programmatically significant because the lower value of the confidence interval is close to one. This is likely due to the collinearity between the wealth index and the education level, where the lower the education level, the lower the respondents' wealth index. This explanation is supported by the results of further bivariate analysis which found that $83.0 \%$ respondents with poor category of wealth index did not finish school, 13.9\% graduated from high school and only 3.1\% were university graduates. About $67.9 \%$ respondents with a middle category of wealth index did not go to school or graduated from high school, $26.6 \%$ graduated from high school and only 5.5\% graduated from university. Families with lower socioeconomic status are more likely to use contraception, which is possibly because they would be unable to afford various needs (education, health, etc.) if they have more children. In addition, the Indonesian government prioritizes family planning services to the poorer population groups. ${ }^{20}$

Women in Java-Bali were more likely to use contraceptives. This is likely because it is related to the condition of infrastructure such as better transportation, health services, etc. in Java-Bali compared to that outside Java-Bali. ${ }^{21}$

Women with good knowledge were more likely to use contraceptives. Similar findings were reported in studies in Myanmar ${ }^{14}$ and Northwest Ethiopia. ${ }^{22}$ This is likely related to exposure to information from health workers, while exposure from the media does not have a significant relationship. Theoretically, behavior change based on sufficient knowledge and high awareness will lead someone to behave better. ${ }^{23}$ Green in his theory also suggests that knowledge is a predisposing factor that influences improved behavior change. ${ }^{24}$

Residing in rural areas and being employed are statistically more likely to use a contraceptive but not programmatically significant because the lower value of the confidence interval is close to one. On the other hand, a study in Nigeria found that those living in rural areas were less likely to use contraceptives $^{25}$ and women's employment status was reported to be unrelated to current contraceptive use. $^{26}$

In our study, the factors found not associated with current contraceptive use were discussions with the husband, having health insurance, family planning information from the media, and field workers visits. A publication that used secondary data analysis of the 1997 and 2007 IDHS found that the most dominant factor related to current contraceptive use was the husband's view of family planning. ${ }^{9}$ In the current analysis, however, discussion with husband is not found to be significantly associated with contraceptive use. It maybe due to the increase of women's autonomy towards contraceptive use. The current finding also differ from a 
study conducted in Burkina Paso where discussions with husbands were found to have an association with contraceptive use..$^{27}$ The insignificant association between information from the media and field workers visit with contraceptive use are likely due to the decreased role of the family planning field workers and the inactive family planning campaign through the media. Findings about media exposure in our study were reported to differ from studies in Afghanistan which showed that family planning information through public and private media was related to contraceptive use..$^{28}$ A study in Bangladesh showed that visits from family planning officers had the highest positive impact on contraceptive use compared to women who did not get a visit. ${ }^{29}$ The results of the 2012 IDHS data analysis in Indonesia showed that those who had health insurance were more likely to use contraceptive but with a lower AOR limit of close to one $(\mathrm{AOR}=1.241 ; 95 \% \mathrm{CI}$ : 1.098-1.404)..$^{30}$

This study is a cross-sectional that does not show a causal relationship. Another limitation is that our study uses secondary data so that analysis can only be conducted using available variables.

\section{CONCLUSION}

The proportion of current contraceptive use in childbearing age women in Indonesia has not reached the government target. Factors that were more likely to increase current contraceptive use were family planning information from health workers, age, region, number of living children, education, and knowledge. Place of residence, employment, and wealth index are statistically significant associated with current contraceptive use but are not programmatically significant because the lower value of the confidence interval is close to one. Unassociated factors were discussions with husbands, insurance, family planning information from the media, and field staff visits. Based on our analysis, the family planning program in Indonesia should therefore consider those factors to increase the current contraceptive use.

\section{ACKNOWLEDGMENTS}

Thanks to the BKKBN for providing online data of 2017 IDHS for our analysis.

\section{REFERENCES}

1. Family Planning 2020. Global contraceptive use rising but more progress needed to reach target: Family Planning 2020 [Internet]. 2018 [cited 2019 Aug 12]. Available from: https://www.familyplanning2020.org/news/global-contraceptive-use-rising-more-progress-needed-reach-target

2. United Nations. World family planning 2017 highlights. United Nations. New York; 2017.
3. Family Planning 2020. Family planning summit: Summary of commitments [Internet]. London; 2017. Available from: http://ec2-54-210-230-186.compute-1.amazonaws. com/wp-content/uploads/2017/09/FP_Summit 2017 Commitment_Summary_Update-V18-Clean.pdf

4. Indonesia Statistics Beureau. Survei Demografi dan Kesehatan Indonesia 2012 [The 2012 Indonesia Demographic and Health Survey]. Indonesia Statistics Beureau. Jakarta; 2013.

5. Indonesia Statistics Beureau. Survei Demografi dan Kesehatan Indonesia 2017 [The 2017 Indonesia Demographic and Health Survey]. Indonesia Statistics Beureau. Jakarta; 2018

6. The National Family Planning Coordination Board. Rencana Strategis Badan Kependudukan dan Keluarga Berencana Nasional Tahun 2015-2019 [The 20152019 Strategic Plan of The National Family Planning Coordination Board]. Jakarta; 2015.

7. Hossain $M$, Khan $M$, Ababneh F, Shaw J. Identifying factors influencing contraceptive use in Bangladesh: Evidence from BDHS 2014 Data. BMC Public Health. 2018;18(1):1-15.

8. Wuni C, Turpin CA, Dassah ET. Determinants of contraceptive use and future contraceptive intentions of women attending child welfare clinics in Urban Ghana. BMC Public Health. 2018;1-9.

9. Rahayu R, Utomo I, Mcdonald P. Contraceptive use pattern among married women in Indonesia. International Conference on Family Planning: Research and Best Practices. Jakarta; 2009.

10. Indonesia Ministry of Health. Buku pegangan sosialisasi jaminan kesehatan nasional (JKN) dalam Sistem Jaminan Kesehatan Nasional [The handbook on the national health insurance program]. Jakarta; 2012.

11. Indonesia Ministry of Health. Peraturan Menteri Kesehatan Republik Indonesia Nomor 28 Tahun 2014 [The 2014 Indonesia Ministry of Health Act No. 28]. Jakarta; 2014 .

12. Indonesia Statistics Beureau. Survei Demografi dan Kesehatan Indonesia 2017 [The 2017 Indonesia Demographic and Health Survey]. Indonesia Statistics Beureau. Jakarta; 2018.

13. Kibira SPS, Muhumuza C, Bukenya JN, Atuyambe LM. "I spent a full month bleeding, i thought i was going to die..." A qualitative study of experiences of women using modern contraception in Wakiso District, Uganda. PLoS One [Internet]. 2015;10(11):1-14.

14. Lwin MM, Munsawaengsub C, Nanthamongkokchai S. factors influencing family planning practice among reproductive age married women in Hlaing Township, Myanmar. Journal of The Medical Association of Thailand. 2013;96 Suppl 5(3):98-106.

15. Eliason S, Awoonor-williams JK, Eliason C, Novignon J, Nonvignon J, Aikins M. Determinants of modern family planning use among women of reproductive age in the Nkwanta District of Ghana: A case-control study. Reproductive Health. 2014;11(1):1-10.

16. Nazir S, Mittal A, Anand BK, Goel RKD, Singh J, Rashid A. Determinants of unmet need for family planning in a developing country: An observational cross sectional study. National Journal of Community Medicine. 2015;6(1):86-91.

17. Odumosu, Ajala AO, Nelson-Twakor EN, Alonge SK. Unmet need for contraception among married man in urban Nigeria. CICRED's Seminar. Nigeria; 2005.

18. Degraff DS, Siddhisena KAP. Unmet need for family planning in Sri Lanka: low enough or still an issue? International Perspectives on Sexual and Reproductive Health. 2015;41(4):200-9.

19. Oktaviana W. Determinan penggunaan kontrasepsi oleh wanita berstatus kawin di daerah perdesaan: Analisis Survei dan Kesehatan Indonesia (SDKI) Tahun 2012 [Determinants of contraception use among married women in rural areas: Analysis of the 2012 Indonesia Demographic and Health Survey]. Buletin Penelitian Kesehatan. 2017;45(4): 257 - 266 
20. Khairani. Pengaruh pemberdayaan perempuan terhadap fertilitas di Provinsi NTT dan DI Yogyakarta (Analisis Data SDKI 2007) [The association between women empowerment and fertility in East Nusa Tenggara and Yogyakarta]. Bulletin Jendela Data dan Informasi Kesehatan. 2013;2(2):1-21.

21. Indonesia Ministry of Health. Profil Kesehatan Republik Indonesia Tahun 2017 [The 2017 Indonesia health profile]. Jakarta; 2018. 107-108 p.

22. Semachew Kasa A, Tarekegn M, Embiale N. Knowledge, attitude and practice towards family planning among reproductive age women in a resource limited settings of Northwest Ethiopia. BMC Research Notes. 2018;11(1):1-7.

23. Gonçalves MJ, Suariyani NLP, Suryadhi NT. Hubungan pengetahuan dan sikap dengan pemakaian alat kontrasepsi pada pus di Puskesmas Comoro Dili Timor Leste [Relationship between knowledge and attitudes with contraceptive use among women of childbearing age at the Comoro Health Centre, Dili, Timor Leste]. Public Health and Preventive Medicine Archive. 2014;2:51-58.

24. Green LW. Modifying and developing health behavior. The Annual Review of Public Health [Internet]. 1984 May 28 [cited 2019 Jul 28];5(1):215-36. Available from: http:// www.annualreviews.org/doi/10.1146/annurev.pu.05. 050184.001243

25. Unumeri G, Ishaku S, Ahonsi B, Oginni A. Contraceptive use and its socio-economic determinants among women in north-east and north-west regions of Nigeria: A Comparative Analysis. African Population Study. $2015 ; 29(2)$.
26. Lamidi EO. State variations in women's socioeconomic status and use of modern contraceptives in Nigeria. PLoS One [Internet]. 2015;10(8):1-16.

27. Wulifan JK, Mazalale J, Jahn A, Hien H, Ilboudo PC, Meda $\mathrm{N}$, et al. Factors Associated with Contraceptive Use among Women of Reproductive Age in Rural Districts of Burkina Faso. J Health Care Poor Underserved. 2017;28(1):228-47.

28. Osmani AK, Reyer JA, Osmani AR, Hamajima N. Factors influencing contraceptive use among women in Afghanistan: Secondary analysis of Afghanistan Health Survey 2012. Nagoya Journal of Medical Sciences. 2015;(July):551-61.

29. Muhammed G, Kibria A, Burrowes V, Majumder S, Sharmeen A, Ara R, et al. Scaling up contraceptives use in the division with lowest contraceptives use in Bangladesh: Sources, methods, and determinants. Maternal Health, Neonatology and Perinatology. 2017;3(10):1-9.

30. Misnaniarti. Women's membership in health insurance and correlation with contraception use in Indonesia. Global Journal of Health Sciences. 2017;9(2).

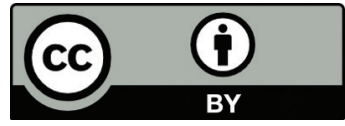

This work is licensed under a Creative Commons Attribution 